\title{
PENINGKATAN PENGETAHUAN KESEHATAN MELALUI EDUKASI PENATALAKSANAAN KEGAWATDARURATAN
}

\author{
Alya Dwiana ${ }^{1}$, Decven Angela ${ }^{2}$, Agnes Marcella ${ }^{3}$ \\ ${ }^{1}$ Bagian Fisiologi , Fakultas Kedokteran, Universitas Tarumanagara Jakarta \\ Email: alyad@fk.untar.ac.id \\ ${ }^{2}$ Mahasiswa Fakultas Kedokteran Universitas Tarumanagara Jakarta \\ Email: decvenangel81@gmail.com \\ ${ }^{3}$ Mahasiswa Fakultas Kedokteran Universitas Tarumanagara Jakarta \\ Email: agnesmarcella2607@gmail.com
}

\begin{abstract}
Education related to emergency cases and their management are very important and practical; in order to increase the number of people, particularly students, who are trained in handling first aid in emergency cases. The purposes of this event are to provide an insight and understanding as well as to socialize first aid skills on emergency cases to lay people. By understanding health and safety factors, positively they can help to prevent unnecessary death. Emergency education and first aid training can increase public knowledge about the potential cases, so that people can implement them in daily life. This will definitely have an impact in increasing positive attitudes on the community. The event is held online using Zoom platform, on Saturday, September 24, 2021 and were attended by 339 participants, mostly medical students. Before and after the presentation, a pretest and a post-test are conducted to assess the knowledge of attending participants regarding emergency education. In general, the participants have better understanding about emergency cases and first aid training after the event.
\end{abstract}

Keywords: Emergency, first aid, insight related to emergency cases and their management

\begin{abstract}
ABSTRAK
Kegiatan Penyuluhan Kesehatan Masyarakat (PKM) berupa edukasi terkait kasus gawat darurat serta tatalaksananya tentunya merupakan hal yang sangat penting dan bermanfaat. Sasaran kegiatan ini adalah terjadinya peningkatan jumlah orang yang terlatih, terutama dikalangan mahasiswa, dalam melakukan tindakan pertolongan pertama pada kasus gawat darurat. Tujuan kegiatan ini adalah memberikan wawasan serta pemahaman kepada masyarakat dan mensosialisasikan sejak dini kegiatan pertolongan pertama pada kasus kegawatdaruratan. Dengan demikan, pertolongan dapat dilakukan dengan memperhatikan unsur kesehatan serta keselamatan dengan tujuan dapat mencegah terjadinya kematian. Edukasi serta pelatihan ini dapat meningkatkan pengetahuan masyarakat mengenai kasus gawat darurat yang berdampak pada peningkatan sikap yang positif pada masyarakat, khususnya dalam kasus kegawatdaruratan serta penatalaksanaannya sehingga masyarakat dapat menerapkan dalam kehidupan sehari-hari. Kegiatan PKM ini dilakukan secara daring (online) dengan menggunakan platform Zoom pada hari Sabtu tanggal 25 September 2021 dan diikuti oleh 339 peserta yang sebagian besar dari kalangan mahasiswa Fakultas Kedokteran. Sebelum dan sesudah penyampaian materi edukasi kasus kegawatdaruratan, dilakukan pretest untuk menilai pengetahuan awal peserta dan post-test bagi peserta untuk menilai pengetahuan setelah mengikuti edukasi terkait kegawatdaruratan. Secara garis besar, terdapat peningkatan pemahaman peserta mengenai tatalaksana kasus kegawatdaruratan (first aid) setelah dilakukan penyuluhan.
\end{abstract}

Kata kunci: Kegawatdaruratan, pertolongan pertama, wawasan terkait kasus gawat darurat serta tatalaksananya

\section{PENDAHULUAN}

Menurut American Heart Association (AHA) keadaan gawat darurat adalah situasi yang menurut pendapat pasien atau keluarganya atau siapa pun yang memikul tanggung jawab membawa pasien ke rumah sakit, memerlukan perhatian medis menengah. Kondisi ini berlanjut sampai keputusan dibuat oleh profesional perawatan kesehatan bahwa kehidupan atau kesejahteraan pasien tidak terancam. Salah satu situasi kegawatdaruratan yang sering terjadi adalah keadaan henti jantung atau jantung tidak berdenyut. Henti jantung dapat terjadi secara tiba-tiba tanpa gejala awal, dapat terjadi dimana saja dan kapan saja. Kondisi ini sering terjadi di lingkungan luar rumah sakit atau disebut Out of Hospital Cardiac Arrest (OHCA). Henti jantung mengakibatkan terjadinya gangguan fungsi vital, dimana denyut nadi tidak teraba dan terjadinya 
henti napas yang mengakibatkan penurunan kesadaran. Kasus henti jantung ini sangat berbahaya jika tidak segera ditolong, dengan prevalensi penyebab 90\% kematian di Amerika Serikat (AHA, 2020). Di Indonesia sendiri masih belum diketahui data yang jelas mengenai pravelensi kejadian henti jantung di kehidupan sehari-hari.

Keadaan darurat merupakan situasi tak terduga yang membutuhkan tindakan penatalaksanaan segera. Kondisi kegawatdaruratan dapat terjadi kapan saja dan di mana saja. Kondisi ini bisa saja terjadi di daerah yang jauh dari keberadaan tenaga kesehatan, oleh karena itu peran serta dari masyarakat sangat diperlukan untuk membantu korban sebelum keadaan gawat darurat ditangani oleh petugas kesehatan (Sudiharto, 2011). Situasi gawat darurat tidak hanya terjadi di tempat yang ramai, seperti di jalan raya dengan lalu lintas yang padat, tetapi bisa juga terjadi di lingkup perumahan ataupun dalam keluarga. Contohnya pada kasus seseorang mendadak terserang penyakit jantung saat atau setelah olahraga, kasus tersedak saat sedang makan, kasus terkilir saat olah raga/aktivitas fisik atau digigit binatang dan sebagainya. Kondisi tersebut harus segera ditangani dalam hitungan menit bahkan dalam hitungan detik karena dapat berpotensi menimbulkan kematian.

Pada keadaan dimana seseorang/pasien berada pada situasi gawat darurat yang mengancam hidupnya, maka pasien memerlukan tindakan pertolongan pertama yang bertujuan mencegah dan menghindari terjadinya kecacatan dan kematian. Dengan membekali dan mempersiapkan diri terhadap kemungkinan terjadinya hal yang tidak terduga tersebut dan mengambil langkahlangkah umum yang sesuai, maka diharapkan dapat meningkatkan kemungkinan hasil yang positif jika situasi darurat tersebut terjadi (American National Red Cross, 2014). Peningkatan pengetahuan serta wawasan praktis kepada masyarakat tentang pertolongan pertama pada kasus gawat darurat memegang peranan yang sangat penting. Dalam hal ini, pertolongan pertama pada kasus gawat darurat merupakan serangkaian langkah awal yang dapat dilakukan pada situasi serta kondisi gawat darurat dalam upaya menyelamatkan pasien dari kematian. Misalnya, jika menghadapi kasus seorang pasien yang mengalami trauma fisik akibat kecelakaan maka diperlukan keterampilan untuk melakukan evaluasi, manajemen jalan napas, bantuan pernapasan, penanganan pada kasus pendarahan, serta transportasi sigap dan aman dari lokasi kejadian menuju rumah sakit.

Untuk melakukan tindakan pertolongan pertama terhadap kondisi kegawatdaruratan ini diperlukan keterampilan serta tingkat pemahaman dan pengertian dalam materi pertolongan pertama pada kecelakaan (P3K/First Aid). Keterampilan P3K adalah keterampilan pertolongan pertama yang harus segera diberikan kepada korban yang mendapatkan kecelakaan atau penyakit mendadak dengan cepat dan tepat, sebelum korban dibawa ke tempat rujukan atau Rumah Sakit. Tujuan dari tindakan P3K adalah untuk menyelamatkan korban, meringankan penderitaan korban, mencegah cidera atau penyakit yang lebih parah dan mencarikan pertolongan yang lebih lanjut (Thygerson, A, 2011; Pfeiffer, R P, 2012).

\section{METODE PELAKSANAAN PKM}

Kegiatan PKM berupa edukasi terkait kasus emergensi serta tatalaksananya merupakan hal yang sangat penting dan bermanfaat, demi tercapainya peningkatan jumlah orang yang terlatih dalam melakukan pertolongan pertama pada kasus emergensi sehingga dapat menjadi bystander di lingkungannya masing-masing. Peningkatan jumlah orang terlatih ini terutama diharapkan dari kalangan mahasiswa. Manfaat kegiatan ini selain dari bertambahnya wawasan serta pemahaman kepada masyarakat terkait keterampilan kegawatdaruratan, juga untuk mensosialisasikan sejak dini kegiatan pertolongan pertama pada kasus kegawatdaruratan yang jika dilakukan dengan memperhatikan unsur kesehatan serta keselamatan dapat mencegah terjadinya kematian.

Edukasi serta pelatihan terkait kasus emergensi dalam kehidupan sehari-hari dapat meningkatkan pengetahuan masyarakat, terutama dikalangan mahasiswa serta dewasa muda. Kegiatan PKM ini 
diharapkan dapat memberi dampak positif pada masyarakat khususnya dalam bertambahnya wawasan terkait kasus kegawatdaruratan serta penatalaksanaannya. Materi PKM yang dipaparkan pada pelatihan meliputi kasus apa saja yang termasuk dalam kasus gawat darurat, penatalaksanaan yang sesuai dalam mengatasi kasus gawat darurat, serta bagaimana teknik yang tepat untuk dapat dilakukan apabila menghadapi kasus kegawatdaruratan. Edukasi kesehatan ini bertujuan untuk meningkatkan pengetahuan dari peserta, khususnya mengenai kasus dan tatalaksana kasus kegawatdaruratan, sehingga diharapkan dapat mempersiapkan peserta dalam menghadapi kasus kegawatdaruratan dan dapat menerapkan pengetahuan tersebut dalam kehidupan sehari-hari. Kegiatan edukasi ini dilakukan secara daring menggunakan platform Zoom, pada hari Sabtu tanggal 25 September 2021. Sebelum dan sesudah presentasi materi edukasi, dilakukan pretest untuk menilai tingkat pengetahuan awal peserta dan post-test untuk menilai tingkat pengetahuan setelah mengikuti edukasi terkait kegawatdaruratan dan tatalaksananya.

\section{HASIL DAN PEMBAHASAN}

Kegiatan seminar dilakukan secara daring dengan menggunakan platform Zoom dan diikuti oleh peserta dari kalangan umum sebanyak 339 orang. Peserta seminar paling banyak berjenis kelamin perempuan (261 orang, 77\%) dan berprofesi sebagai mahasiswa Fakultas Kedokteran (325 orang, 95.87\%). Peserta seminar juga didominasi kelompok usia 18 tahun (115 orang, $33.92 \%$ ), dengan usia termuda adalah 16 tahun dan usia tertua 43 tahun (Lihat Tabel 1).

Tabel 1 Karakteristik Peserta Seminar

\begin{tabular}{lccc}
\hline Karakteristik & $\mathrm{N}=339$ & $\%$ & Min \\
\hline Usia (tahun) & 2 & 0.58 & 16 tahun \\
16 tahun & 34 & 10.02 & \\
17 tahun & 115 & 33.92 & \\
18 tahun & 55 & 16.22 & \\
19 tahun & 67 & 19.76 & \\
20 tahun & 47 & 13.86 & \\
21 tahun & 9 & 2.65 & \\
22 tahun & 3 & 0.88 & \\
23 tahun & 3 & 0.88 & \\
25 tahun & 1 & 0.29 & \\
26 tahun & 1 & 0.29 & \\
28 tahun & 1 & 0.29 & \\
43 tahun & 1 & 0.29 & \\
Jenis Kelamin & & & \\
Perempuan & 261 & 77.00 & \\
Laki-laki & 78 & 23.00 \\
\hline Profesi/Pekerjaan & & & \\
Pelajar & 4 & 1.18 \\
Mahasiswa Kedokteran & 325 & 95.87 \\
Mahasiswa Keperawatan & 1 & 0.29 \\
Mahasiswa D4 Anestesiologi & 3 & 0.88 \\
Dokter Umum & 3 & 0.88 \\
Karyawan Swasta (Non-medis) & 3 & 0.88 \\
\hline
\end{tabular}

Sebelum dilakukan penyuluhan, peserta diminta untuk menjawab soal pre-test yang bertujuan untuk mengetahui sejauh mana pemahaman peserta mengenai kasus gawat darurat dan tatalaksananya. Ada 6 pertanyaan yang diajukan yaitu: apakah tindakan FIRST AID yang tepat pada orang dengan gangguan kesadaran, apakah penanganan yang tepat pada pasien dengan 


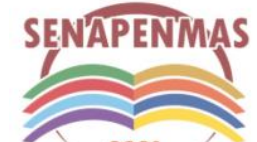

kejang, apakah pertolongan pertama pada pasien dengan asma, apa tindakan pertama yang harus dilakukan bila terjadi strain (keseleo), bagaimana pertolongan pertama pada cedera akibat bahan kimia, dan apakah benar/salah jika luka akibat gigitan ular diposisikan lebih rendah dari jantung. Setelah dilakukan penyuluhan oleh pakar kesehatan dan dilakukan sesi diskusi serta tanya jawab, peserta kembali diminta menjawab soal post-test dengan pertanyaan yang sama. Hal ini bertujuan untuk mengetahui apakah dengan mengikuti penyuluhan, peserta sudah lebih mengetahui dan paham mengenai kasus kegawatdaruratan dan talaksananya. Terdapat perbedaan jumlah peserta yang mengisi kuesioner pretest dan postest, dimana terdapat 339 peserta pada pretest $(\mathrm{N}=339)$ dan 302 peserta pada postest $(\mathrm{N}=302)$. Lihat Gambar 1 untuk dokumentasi kegiatan penyuluhan.
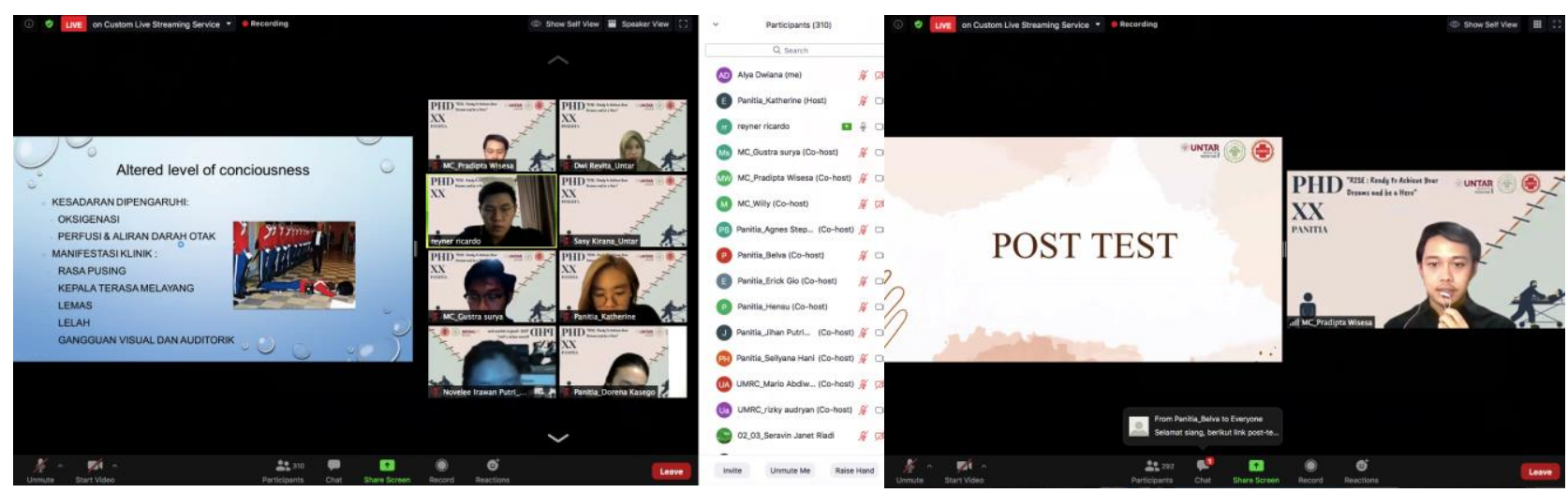

Gambar 1 Dokumentasi Kegiatan Penyuluhan

(Sumber: Dokumentasi Pribadi, 2021)

Sebelum dilakukan penyuluhan, pada kuesioner ditanyakan apakah peserta mengetahui tindakan FIRST AID yang tepat pada orang dengan gangguan kesadaran, dimana sebagian besar peserta sudah mengetahu jawaban yang benar yaitu melakukan evaluasi jalan napas dan denyut jantung (tanda-tanda vital) (75.8\%). Setelah dilakukan penyuluhan, terjadi sedikit penurunan jumlah peserta yang menjawab dengan benar (72.8\%). Pertanyaan kedua kuesioner menanyakan apakah peserta mengetahui penanganan pasien dengan kejang yang tepat, dimana jawaban yang benar adalah membaringkan pasien dalam posisi miring ke kiri/kanan (recovery position). Hasilnya adalah terjadi peningkatan jawaban yang benar dari $23.9 \%$ sebelum penyuluhan menjadi $35.8 \%$ setelah penyuluhan. Dalam hal ini, sebagian besar peserta masih belum memahami tatalaksana pertama yang tepat untuk kasus kejang. Tetapi untuk pertanyaan ini bisa dimengerti karena peserta yang sebagian besar masih termasuk kalangan awam (mahasiswa), sehingga lebih cenderung memilih jawaban awam yaitu memprioritaskan menahan lidah agar tidak tergigit. Jawaban ini menurut medis tidak tepat dan berpotensi membahayakan pasien. Pertanyaan ketiga kuesioner, mempertanyakan apakah peserta mengetahui apa pertolongan pertama pada pasien dengan asma. Jawaban yang tepat adalah dengan membantu pasien menggunakan inhaler jika pasien memilikinya. Disini, mayoritas peserta baik sebelum maupun sesudah penyuluhan sudah mengetahui jawaban yang benar (76.7\% dan $77.5 \%)$. Pertanyaan keempat adalah tindakan pertama apa yang harus dilakukan bila terjadi strain (keseleo), dimana jawaban yang tepat adalah dengan memposisikan area yang cedera lebih tinggi dari jantung. Sebelum penyuluhan, kurang dari separuh jumlah peserta yang tidak mengetahui jawaban yang benar. Sedangkan sesudah penyuluhan, terdapat kenaikan jumlah peserta yang menjawab dengan benar (sebelum - 41.9\%, sesudah - 49.7\%). Pertanyaan kelima adalah mengenai apakah peserta mengetahui bagaimana pertolongan pertama pada cedera akibat bahan kimia. Hasilnya adalah 
sebagian besar peserta, baik sebelum maupun sesudah penyuluhan, mengetahui bahwa luka akibat bahan kimia harus dicuci dengan air bersih $(79.4 \%$ sebelum dan $81.1 \%$ sesudah). Pertanyaan terakhir adalah mengenai apakah benar/salah luka akibat gigitan ular harus diposisikan lebih rendah dari jantung. Dalam hal ini, baik sebelum maupun sesudah penyuluhan mayoritas peserta menjawab dengan benar, dimana adalah benar bahwa luka akibat gigitan ular harus diposisikan lebih rendah dari jantung (78.8\% sebelum dan $85.1 \%$ sesudah). Perbandingan tingkat pengetahuan peserta sebelum dan sesudah penyuluhan dapat dilihat pada Tabel 2.

Tabel 2 Pemahaman Peserta Mengenai Kegawatdaruratan dan Tatalaksananya Sebelum dan Sesudah Mengikuti Penyuluhan

\begin{tabular}{|c|c|c|c|c|}
\hline No & Pertanyaan & Respon & $\begin{array}{c}\text { Pre-Test } \\
(\mathrm{N}=339)\end{array}$ & $\begin{array}{l}\text { Post-Test } \\
(\mathrm{N}=302)\end{array}$ \\
\hline 1. & $\begin{array}{l}\text { Apakah tindakan FIRST AID } \\
\text { yang tepat pada orang dengan } \\
\text { gangguan kesadaran? }\end{array}$ & $\begin{array}{l}\text { Menjawab Benar } \\
\text { Menjawab Salah }\end{array}$ & $\begin{array}{l}257(75,8 \%) \\
82(24.2 \%)\end{array}$ & $\begin{array}{l}220(72.8 \%) \\
82(27.2 \%)\end{array}$ \\
\hline 2. & $\begin{array}{l}\text { Apakah penanganan pasien } \\
\text { dengan kejang yang tepat? }\end{array}$ & $\begin{array}{l}\text { Menjawab Benar } \\
\text { Menjawab Salah }\end{array}$ & $\begin{array}{l}81(23.9 \%) \\
258(76.1 \%)\end{array}$ & $\begin{array}{l}108(35.8 \%) \\
194(64.3 \%)\end{array}$ \\
\hline 3. & $\begin{array}{l}\text { Apakah pertolongan pertama pada } \\
\text { pasien dengan asma? }\end{array}$ & $\begin{array}{l}\text { Menjawab Benar } \\
\text { Menjawab Salah }\end{array}$ & $\begin{array}{l}260(76.7 \%) \\
79(23.3 \%)\end{array}$ & $\begin{array}{l}234(77.5 \%) \\
68(22.5 \%)\end{array}$ \\
\hline 4. & $\begin{array}{l}\text { Bila terjadi strain (keseleo), } \\
\text { apakah tindakan pertama yang } \\
\text { harus dilakukan? }\end{array}$ & $\begin{array}{l}\text { Menjawab Benar } \\
\text { Menjawab Salah }\end{array}$ & $\begin{array}{l}142(41.9 \%) \\
197(58.1 \%)\end{array}$ & $\begin{array}{l}150(49.7 \%) \\
152(50.3 \%)\end{array}$ \\
\hline 5. & $\begin{array}{l}\text { Bagaimanakah pertolongan } \\
\text { pertama pada cedera akibat bahan } \\
\text { kimia? }\end{array}$ & $\begin{array}{l}\text { Menjawab Benar } \\
\text { Menjawab Salah }\end{array}$ & $\begin{array}{l}269(79.4 \%) \\
70(20.7 \%)\end{array}$ & $\begin{array}{c}245(81.1 \%) \\
57(18.9 \%)\end{array}$ \\
\hline 6. & $\begin{array}{l}\text { Apakah benar/salah jika luka } \\
\text { akibat gigitan ular harus } \\
\text { diposisikan lebih rendah dari } \\
\text { jantung? }\end{array}$ & $\begin{array}{l}\text { Menjawab Benar } \\
\text { Menjawab Salah }\end{array}$ & $\begin{array}{l}267(78.8 \%) \\
72(21.2 \%)\end{array}$ & $\begin{array}{l}257(85.1 \%) \\
45(14.9 \%)\end{array}$ \\
\hline
\end{tabular}

\section{KESIMPULAN DAN SARAN}

Kegiatan pengabdian kepada masyarakat dengan topik "Peningkatan Pengetahuan Kesehatan Melalui Edukasi Penatalaksanaan Kegawatdaruratan" dilaksanakan dengan baik dan lancar pada hari Sabtu tanggal 25 September 2021. Kegiatan dihadiri oleh 339 peserta. Kegiatan penyuluhan ini lebih banyak dihadiri oleh kelompok usia 18 tahun, dimana usia yang termuda adalah 16 tahun dan yang tertua adalah 43 tahun. Pada kegiatan ini dilakukan pretest dan postest untuk menilai tingkat pemahaman peserta sebelum dan sesudah penyuluhan. Hasilnya didapatkan secara garis besar terdapat peningkatan pemahaman peserta terhadap tatalaksana kasus kegawatdaruratan.

Untuk kegiatan PKM berikutnya, disarankan untuk dilakukan penyuluhan yang lebih detil dengan bahasa yang lebih mudah dimengerti mengenai Tatalaksana Kegawatdaruratan dalam kehidupan sehari-hari. Akan lebih baik jika disertai dengan kegiatan workshop dimana peserta bisa terlibat secara langsung/real dalam menghadapi kasus-kasus kegawatdaruratan dan tatalaksananya (first aid). Diharapkan peserta dapat memiliki pemahaman yang lebih dalam dan dapat mematahkan mitos-mitos orang awam tentang tatalaksana kegawatdaruratan yang terkadang tidak tepat dan cenderung membahayakan nyawa pasien.

\section{Ucapan Terima Kasih (Acknowledgement)}

Penulis menyampaikan terima kasih kepada Lembaga Penelitian dan Pengabdian kepada Masyarakat UNTAR atas pendanaan dalam kegiatan ini. Terima kasih juga disampaikan kepada seluruh peserta yang telah mengikuti kegiatan bakti kesehatan ini, sehingga kegiatan dapat 
terlaksana dengan baik dan lancar. Terima kasih juga kepada Panitia SENAPENMAS yang sudah memberikan kesempatan untuk berpatisipasi pada kegiatan SENAPENMAS 2021.

\section{REFERENSI}

American Heart Association, (2020), CPR guidelines tackle health disparities, management of opioid-related emergencies and physical, emotional recovery. diakses dari https://newsroom.heart.org/news/updated-cpr guidelines-tackle-health-disparitiesmanagement-of-opioid-related-emergenciesand-physical-emotional-recovery-6817716

American National Red Cross. (2014). American Red Cross Frist Aid/CPR/AED: Participant's Manual. StayWell Health \& Safety Solutions. http://www.thprd.org/document/4085/american-red-cross-first-aidcpraed-participantmanual

American National Red Cross. (2020). American Red Cross Frist Aid/CPR/AED https://gmedicalcpr.com/cpr-first-aid-class/wp-content/uploads/2020/08/g-medic-a-cprprovider-manual.pdf

Hutabarat, R. Y.\& Putra, C. S. (2016). Asuhan Keperawatan Kegawatdaruratan (1st ed.). Bogor: IN MEDIA.

Kushayati, et al., (2019). The influence of health education to improve community knowledge of basic life support procedure in Dlanggu district, Mojokerto regency, Indonesia. Diakses Journal of Public Health in Africa. 2019 Special Issue, Vol. 10, p78-80. 3p. diakses dari https://www.publichealthinafrica.org/index.php/jphia/article/view/1191

Sudiharto, S. 2011. Basic Trauma Cardiac Life Support. Jakarta: CV. SagungSeto

Thygerson, A. (2011). First Aid. Jakarta: Erlangga. Diterjemahkan oleh Huriawati.

Pfeiffer, R P. (2012). Sports First Aid. Jakarta: Erlangga. Diterjemahkan oleh Huriawati 